\title{
Following the Roots of Oregon Wine
}

\author{
Rachael Cristine Woody \\ Linfield College \\ Rich Schmidt \\ Linfield College
}

Follow this and additional works at: https://digitalcommons.linfield.edu/librariesfac_pubs

Part of the Archival Science Commons, and the History Commons

\section{DigitalCommons@Linfield Citation}

Woody, Rachael Cristine and Schmidt, Rich, "Following the Roots of Oregon Wine" (2013). Faculty \& Staff Publications. Published Version. Submission 8.

https://digitalcommons.linfield.edu/librariesfac_pubs/8

This Published Version is protected by copyright and/or related rights. It is brought to you for free via open access, courtesy of DigitalCommons@Linfield, with permission from the rights-holder(s). Your use of this Published Version must comply with the Terms of Use for material posted in DigitalCommons@Linfield, or with other stated terms (such as a Creative Commons license) indicated in the record and/or on the work itself. For more information, or if you have questions about permitted uses, please contact digitalcommons@linfield.edu. 


\section{Following the Roots of Oregon Wine}

\section{by Rachael Cristine Woody and Rich Schmidt}

EACH BOTTLE OF WINE has its own story of origin and evolution. Understanding those unique stories can add new layers of complexity and enjoyment to both the wine-drinking experience and the knowledge of regional history. Humans have been making and drinking wine since the birth of civilization in the Fertile Crescent, with each region producing a distinctive flavor. ${ }^{1}$ To feel the earthy tones and delicate notes of an Oregon wine roll across your tongue is to experience the notion of terroir - a French term widely used in wine circles to mean "the taste of the place." Soil, weather, and the personality of the winemaker each play a role in how a wine will taste, age, and represent the specific vineyard from which it came. ${ }^{2}$ The human elements that contribute to terroir explain why a region can have dozens of wineries with each having its own unique taste. The terroir of Oregon wine also reveals the histories of grape growers and winemakers as well as consumers and the social, economic, and ecologic context in which they have lived. A new archive at Linfield College - the Oregon Wine History Archive (OWHA) - collects that history and makes it available to researchers and the public.

Similar to any good blend of wine, OWHA was conceived in a confluence of the right events and people. With the unlikely partnership of an American Baptist school and the wine community, the International Pinot Noir Celebration (IPNC) made its home at Linfield College in 1987, and during the next two decades, the school's interest in the wine industry gradually grew. The spark came when the Linfield Center for the Northwest paired with IPNC to create an exhibit and documentary to celebrate IPNC's twenty-fifth anniversary in $2011 .^{3}$ Linfield faculty conducted interviews with modern-day winemakers in the Willamette Valley and created displays of accumulated historical artifacts, all of which generated excitement among both the winemakers and Linfield staff. Both groups agreed that the collaboration should not stop 


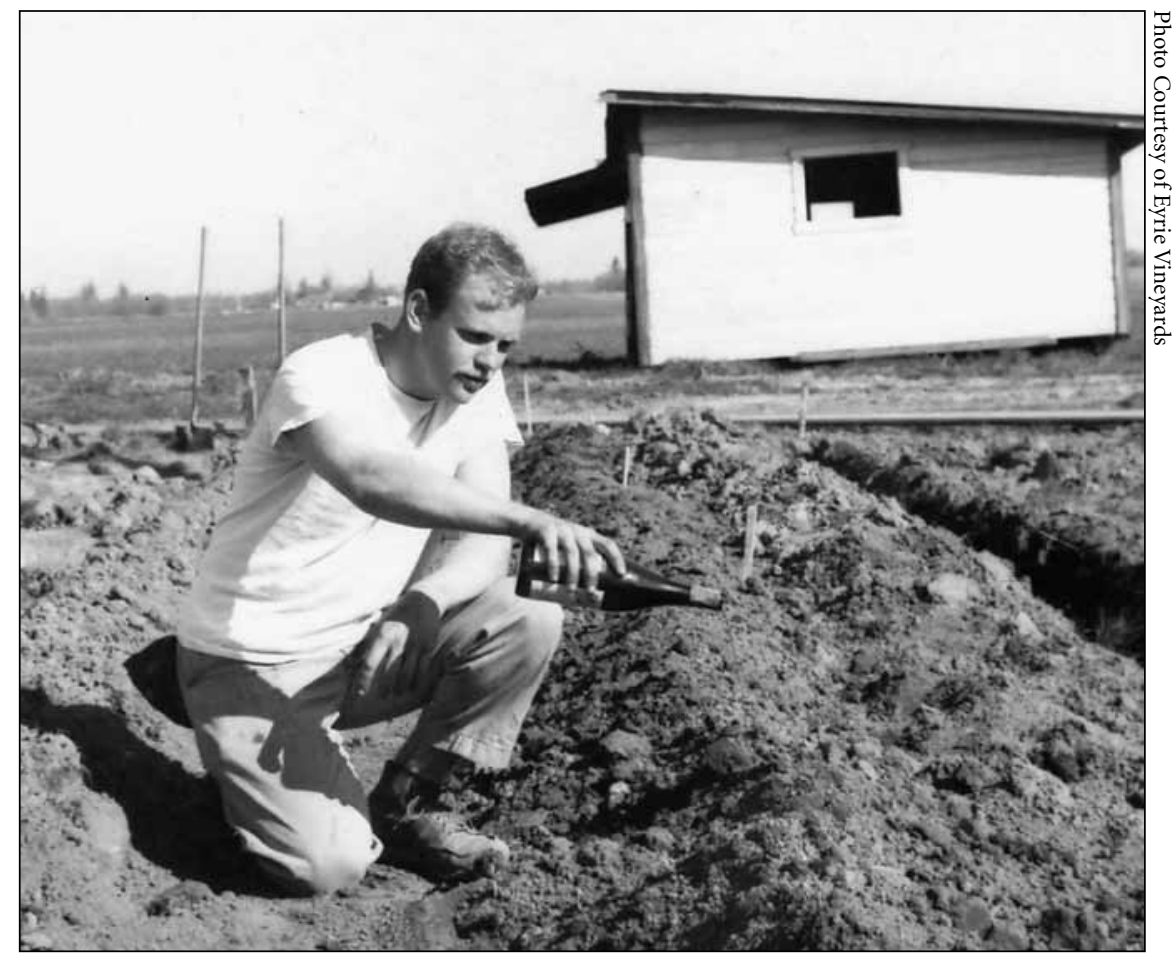

In 1965, David R. Lett christened the first planting at The Eyrie Vineyards in the Willamette Valley. Eyrie Vineyards '75 pinot noir placed in the top ten in 1979 at a wine competition in Paris held by French food and wine magazine Gault Millau.

there. Linfield library staff had previously secured appropriate archives space and funding and had hired a consultant to establish policies and procedures for the department. In November 2011, Linfield College hired its first archivist charged with both running the college archives and creating OWHA. OWHA's initial collection goals were to acquire six collections from committed Willamette Valley winery owners; within a year, the objective of the collection grew to include the documentation of every facet of the Oregon wine industry. OWHA works with other regional institutions to make materials available to researchers and to actively explore and reveal areas of the industry that highlight Oregon wine's origin.

Knowing more about the Oregon wine industry's history not only fills gaps in regional history but also adds an additional element to each bottle's terroir, generating more respect and excitement around its consumption. Until recently, the history of Oregon wine primarily had been kept by the state's grape growers and winemakers with little outside access or active research. Winemakers and vineyard 


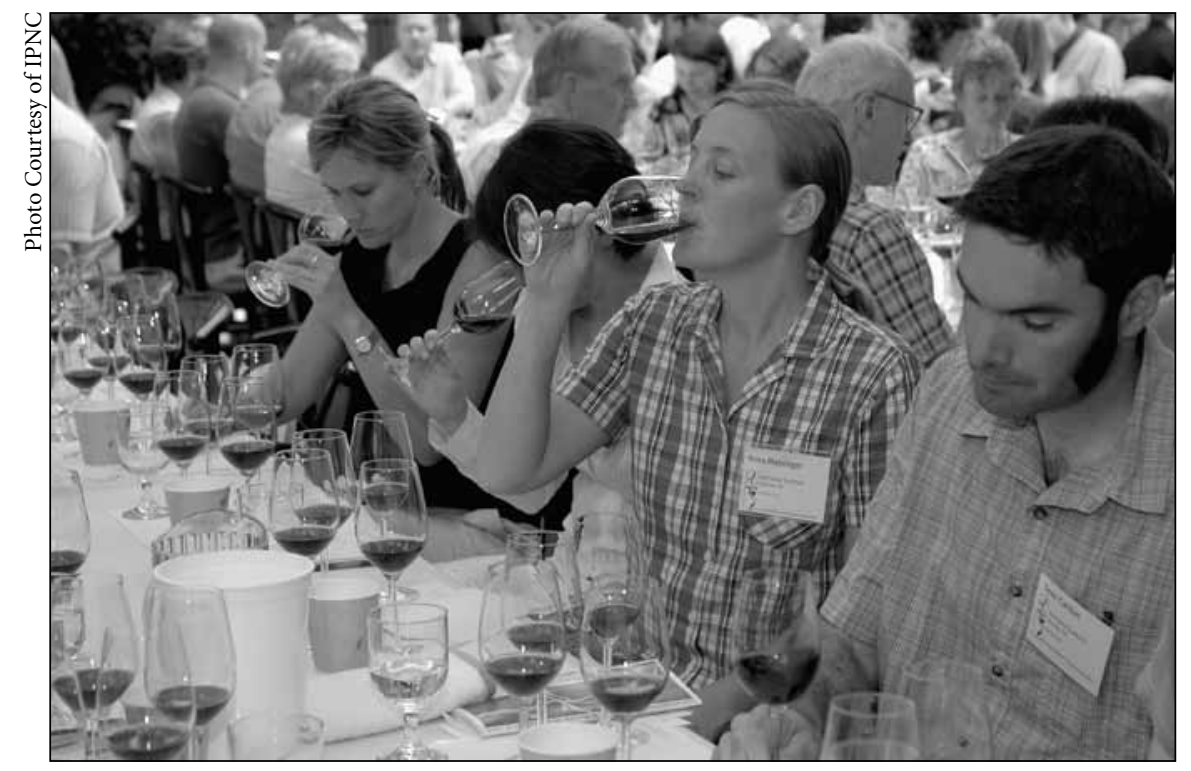

Anna Matzinger (center) and Sean Carlton (far right) of Archery Summit Winery participate in a wine tasting at the International Pinot Noir Celebration (IPNC) in 2005. Now in its twenty-seventh year, IPNC annually brings creators and connoisseurs of pinot noir from around the world to Linfield College in McMinnville.

managers remember for a given year what the weather was like, the crop yield, the flavor of wine that emerged, how it aged, and many other details. They have kept scribbled notes about the weather, grape-sugar measurements, and aspects of wine blending and vineyard tending that provide detail on the terroir elements of the wines and on the industry as well. OWHA is dedicated to collecting those details. As the collection has grown, an increasing number of elements and themes emerges that tell the story of Oregon wine and the Willamette Valley's flagship varietal: pinot noir. As much as terroir has to do with the place, it has just as much to do with the people.
OWHA chronicles the Oregon wine industry by documenting all aspects of the industry and collecting and preserving historical materials from winery owners, growers, researchers, marketers, workers, and sellers. Archival materials include: photographs, diaries, scrapbooks, audio and video files, planting notes, crop reports, documentation of plant-disease epidemics, tasters' notes, wine recipes, notebooks, correspondence, maps, committee minutes, newsletters, legislative records, wine labels, information about local and international cooperation, advertising materials, business records, newspaper articles, and bottles of wine. Although OWHA was just founded in 2011, it currently holds 
collections from more than a dozen wineries, vineyards, individuals and organizations, including: Erath Winery, Ponzi Vineyards, Amity Vineyards, WillaKenzie Estate, Sokol Blosser Winery, Tualatin Estate Vineyards, Rex Hill Winery and Estate, Weber Vineyard, McDaniel Vineyard, Fuqua Vineyards, author Janis Miglavs, the International Pinot Noir Celebration, the Oregon Wine Board, Oregon Pinot Camp, and ¡Salud! health-care program. Agreements to donate collection materials have been received from Eyrie Vineyards, Adelsheim Vineyard, and several additional members of the Oregon wine industry. Many of the area's winemakers are engaged in creating ongoing contributions to the archive as they continue to create the history of Oregon wine. OWHA therefore collects contemporary materials of historical significance, focusing less on age than importance. Capturing oral histories with current winemakers and industry workers is just as important a component of our work as preserving their past and present documents for future use.

At a reception marking the opening of OWHA, Dick Erath said, with a mischievous twinkle in his eye: "You know, back then, we didn't know what we were doing!" This statement was hard to believe, coming from a man whose wine is internationally known, but he and a dozen or so grape growers and wine enthusiasts truly revitalized an industry that had been dormant in Oregon for decades. When they arrived, beginning in the mid 1960s, "Oregon was virgin territory for ... the wine pioneers who came into the valley with dreams as hopefully romantic as those of any early settler." 4

Nineteenth-century settlers, predominantly European immigrants, had brought vines among their most treasured possessions en route to Oregon. Henderson Luelling planted the first grapes in the Willamette Valley in about 1847 . Despite naysayers who thought it would not be a viable business, Peter Britt started Valley View Vineyard in the Rogue Valley in 1852 ; it was the first recorded commercial vineyard in Oregon. ${ }^{5}$ Ernst Reuter continued the first pioneer plantings of vitis vinifera and later won a medal for his Riesling at the 1904 St. Louis World's Fair. ${ }^{6}$ Jesse Applegate established vineyards in Yoncalla and the Umpqua Valley in the 1870s, and later in the century, the Doerners and Van Pessels followed. ${ }^{7}$

Oregon's early winemakers were able to successfully yield hundreds of acres of grapes and produce profitable and award-worthy wines at a time when the region lacked large urban centers. ${ }^{8}$ Unfortunately for the burgeoning industry, Prohibition went into effect early in the twentieth century, and anti-alcohol sentiment forced the closure and eventual loss of the majority of Oregon's early vineyards. ${ }^{9}$ Oregon pushed for prohibition in 1914, five years before national Prohibition, and it remained in effect in Oregon until the end of $1933 .{ }^{10}$ During the nearly twenty years of Prohibition, Oregon's first winemakers had to close their doors and let their fields go fallow or convert them into other fruit crops. Only a few survived Prohibition by bootlegging 
or making wine for religious rituals. After 1933, any organization that wanted to produce wine had to apply to the Oregon Liquor Control Commission (OLCC), the state agency created to regulate alcohol and spirits. ${ }^{11}$ Honeywood (in Salem) is the state's oldest continuously operating winery, founded shortly after the repeal of Prohibition, but from 1934 into the 1970s, the number of bonded wineries in Oregon increased to only twenty. ${ }^{12}$

During the 1960s, however, Oregon began to receive attention from a new generation of winemakers, many of whom lived and trained in California before coming north. The University of California at Davis (UC Davis) had begun its modern viticulture program in 1935, revitalizing a pre-Prohibition state mandate from 1880 to provide research on viticulture. ${ }^{13}$ The program and others like it attracted young adults to the West and, by the late 1960s, many had turned their focus toward the earth, examining how land is used and what kind of life was worth living. As Dick Ponzi recalled:

In the late' 60 , there was a lot of unrest going on, a lot of things going on in California that we didn't like. We were somewhat idealist in a way. Many of us wanted to get back to the land. ${ }^{14}$

For him and others, growing wine was a romantic venture, driven by a desire to break with society's conventions. David Adelsheim explains:

When we started in 1971 , it was a pretty special time in America. It was a continuation of the 1960 in terms of the freedom. People were given permission to do something that they wanted to do rather than what they had studied or what their parents did. There was a huge generational shift. ${ }^{15}$

Several of those young adults decided to express that freedom through winemaking in Oregon. Erath and the others were instilled with California viticulture knowledge and knew how to grow grapes, and they wisely choose to focus on pinot noir, a coolclimate grape that was more likely to succeed in the Willamette Valley than warm-climate grapes such as cabernet or syrah. Still, their ability to produce quality pinot noir wine in Oregon was no guarantee.

Charles Coury was among the first winemakers to come from California to Oregon during the mid twentieth century. His 1952 University of California dissertation introduced many others to the argument that, when an ideal climate and land were found, it would be possible to grow and produce pinot noir that could rival France's Burgundy. ${ }^{16}$ Many professors at UC Davis, however, remained skeptical, cautioning their students that pinot noir grapes could not be grown in Oregon. ${ }^{17}$ In spite of that discouragement, many of the modern-day Oregon winemakers set off for the cool-climate valleys of Oregon during the late 1960 s and early 1970 . They included Coury, Dick Erath, David and Diana Lett, Bill and Susan Sokol Blosser, and Dick and Nancy Ponzi - all of whom are now widely recognized as successful innovators in Oregon's wine industry. ${ }^{18}$

Based on their research, the twentieth-century winemakers believed the Willamette Valley - with its 


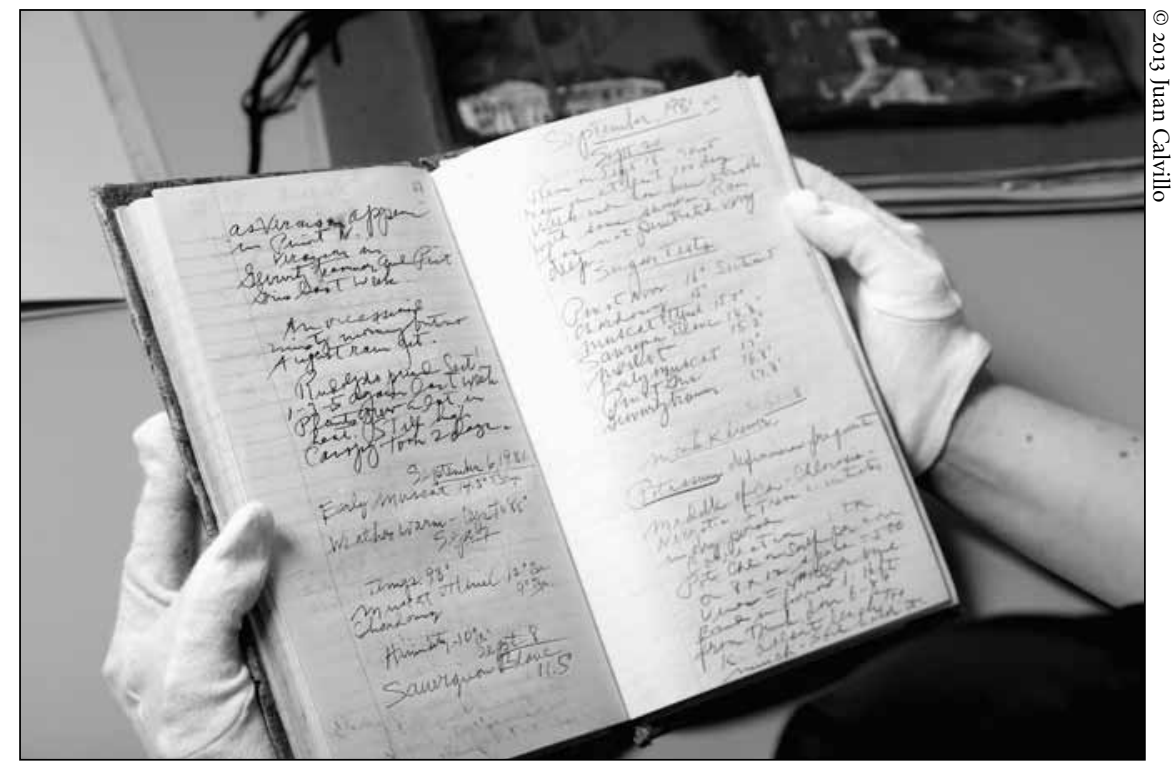

James McDaniel's notebook contains notes from plantings at his vineyard. McDaniel recorded planting sizes, sugar content, and every other important measurement in the notebook, which serves as a record of the day-to-day work of growing grapes.

cool climate, topography, and proven agricultural history - could be the place Coury described. Many who traveled north to the Willamette Valley stopped at HillCrest Vineyard in Roseburg, owned by Richard Sommer, which was the first post-Prohibition winery to commercially plant and bottle pinot noir in the state. Sommer is widely viewed by his peers as the father of the Oregon wine industry. ${ }^{19}$ According to Dick Erath:

When I was living in Walnut Creek, California, I took a course at UC Davis about making wine. I asked one of the professors, Vern Singleton, "What's going on in the Pacific Northwest?" He told me, "Talk to the guy in the back of the classroom there. He's from Oregon." It was Richard Sommer from Roseburg, and he couldn't wait to give me a bottle of wine that he had made. ${ }^{20}$
Many of the early Oregon winemakers recount stopping to see Sommer for advice, wine, and encouragement to get them through the hard work that lay ahead.

Whether intentionally or not, Sommer's kindness and generosity set the tone for attributes common to the Oregon wine industry today: neighborliness, collaboration, and cooperation. Countless stories of mentorship, life-long friendship, and general helpfulness can be found within OWHA collections. If a neighbor had a tractor break down or ran out of wine bottles or needed an extra hand, all they had to do was ask. Susan Sokol Blosser summed it up succinctly: "We were the underdogs, and underdogs sort of stick together." ${ }^{21}$ This sentiment helped 
unite Oregon wine-industry members with three common purposes: protecting the land, improving the quality of wine, and caring for all wine-industry workers. Those commitments are well documented in OWHA collections.

Early winemakers recognized that, for the Oregon wine industry to grow and thrive throughout the decades, they would need to protect prime agricultural land. David Lett and David Adelsheim used U.S. Geological Survey maps to highlight potential vineyard locations and emphasized that those locations should be protected from urban growth. They and others lobbied county planning committees about where residential growth should be restricted. OWHA offers these maps online through DigitalCommons@ Linfield and receives requests from potential grape growers wishing to know the ideal location to start their business. $^{22}$

Documentation and correspondence within OWHA collections demonstrate the lobbying efforts of Oregon winemakers who worked to implement or fight against legislation to improve the quality of wine and encourage growth in the industry. Among the legislation they provided testimony against were House Bills 2145 (1977) and 2482 (1977), which they felt would have slowed business in the late 1970s. House Bill 2145 would have added an additional sales tax (or revoked an existing tax exemption) on alcoholic beverages to pay for drug and alcohol rehabilitation. House Bill 2482 would have required winemakers to attempt to reuse all wine bottles at a time when the potential reuse was limited. The bill would have required wine makers, distributors, and retailers to collect and clean every bottle to determine if it could be used again. If not, they would then be responsible for the bottle's disposal. The wine industry argued that it did not have sufficient means to pay the extra taxes and that the costs would be passed along to consumers. ${ }^{23}$

According to the archives, it does not appear as though either bill passed. What is clear is that, by the late 1970s, Oregon winemakers had determined the need for a unified voice before the legislature. On January 9, 1979, Bill Nelson, a wine lobbyist and former director of the Oregon Winegrowers Association wrote:

The 1977 Legislative session marked the first use by winegrowers/producers in Oregon of professional representation. Until that time, the industry had relied on its own members to directly make industry views known to the legislature and other governmental bodies. Those early efforts were, if anything, counterproductive. The industry spoke with divided and contradictory voices and managed in the process either to alienate or hopelessly confuse its supporters while giving a clear path to its detractors. The net results were negative. Taxes were raised without special consideration for the Oregon industry, pleas for increased research were largely ignored, and the image of the industry became one of novices crying out for someone else to take care of their problems. ${ }^{24}$

As Nelson states, a strong and cohesive voice was needed for the Oregon wine industry to continue growing, and the industry realized that need and worked toward it in a variety of ways. 
In addition to working with the legislature, Oregon winemakers also care for the land on which their industry operates. The Amity and Sokol Blosser collections in OWHA document the industry's current and continued push toward environmental sustainability with recent work in Leadership in Environmental and Energy Design (LEED), Low Input Viticulture and Enology (LIVE) and Salmon Safe programs. ${ }^{25}$ Sokol Blosser Winery has installed solar panels and controls its water runoff to ensure it does not adversely affect local water sources. Across the Dundee Hills to the Jory Hills, the gravity-flow WillaKenzie Estate has heavily implemented LIVE by refusing to remove anything but invasive plant species in order to leave the environment as natural as possible. Amity Vineyards produced the state's first sulfite-free wine from organically grown grapes in 1990 and continues to make organic wine today, a decision that has proved fortuitous as the organic consumer trend continues to gain momentum, especially in the Pacific Northwest. Much of this work has been done in the past decade, demonstrating that the Oregon winemakers' commitment to environmental responsibility has continued into their children's generation.

The most extraordinary of the efforts to improve the quality of all Oregon wine was the passing of legislation that required consensus among those in the industry and helped it compete and succeed in both national and international wine markets. In
1977, Oregon winemakers worked to establish a labeling law known as ORS Chapter 471. Documentation and coordination of drafts of this legislation can be found in OWHA's Erath and Amity collections. One such document is the April 6, 1977, minutes of the Winegrowers Council of Oregon executive board, in which Dick Erath leads a discussion on which adjectives will be acceptable to use on wine labels. ${ }^{26}$ The labeling law established a 90 percent minimum varietals content, meaning that in order to label a wine "pinot," it had to be made from at least 90 percent pinot grapes - much higher than the national standard of 75 percent. The law included similar standards for regional naming. If a wine claimed to be from Oregon, at least 95 percent of its grapes needed to come from Oregon. Every licensed winery in Oregon had to sign off on the law in order for it to be submitted for OLCC's consideration. The effort quickly proved worthwhile because it raised the standard for Oregon wine and helped the state's winemakers gain the trust and respect of French winemakers, who had been frustrated by what they saw as labeling misrepresentation in California. Oregon winemakers benefited from that trust.

In the same year that they defined strict labeling standards, Oregon wine- industry members established a tax on themselves to support a research position at Oregon State University (OSU) that would lead to better winemaking and better pinot noir. Barney Watson, who was hired for the position, offered workshops 


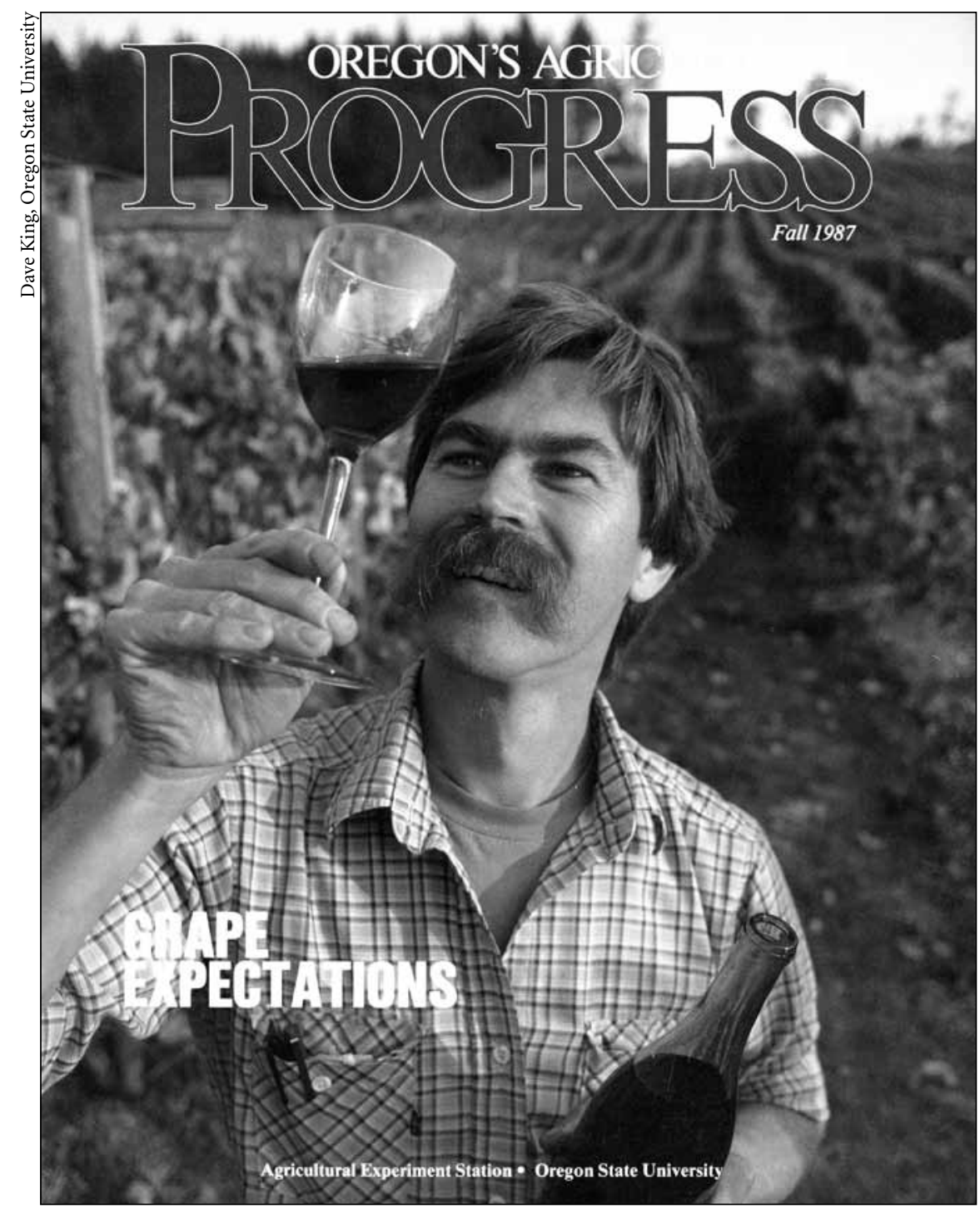

Barney Watson was hired in 1977 for a research position at Oregon State University that the wine industry funded with a self-imposed tax. Watson led research efforts and workshops that helped Oregon winemakers as they continued to hone their skills.

and winery visits, researched the ideal yeast and wine bacteria, created best practices for winemaking, and standardized planting management.
In addition to the efforts at OSU, Charles Coury helped lead research to determine the best clones. ${ }^{27}$ Dick Erath explained that "in 1977 France 
granted special permission to have clones imported to the United States Department of Agriculture, which set up a satellite site at Oregon State University." ${ }^{28}$ This self-imposed tax also required that winemakers work with the state legislature to create a special advisory board for oversight.

With roughly a decade of pinot noir production and intensive efforts to hold the industry to high standards, Oregon wine began to receive international attention by the late 1970s. In 1979, the Eyrie Vineyards ' 75 pinot noir placed in the top ten at a wine competition in Paris held by French food and wine magazine Gault Millau. That ranking was the first major worldwide recognition for Oregon's pinot noir. Robert Drouhin - considered royalty in Burgundy winemaking circles — was so shocked that he demanded a rematch in early 1980. Eyrie's entry placed second to Drouhin's '59 Burgundy. ${ }^{29}$ Drouhin became intensely curious about how Oregon's wine industry could possibly compete with centuries of Burgundian tradition after such a short amount of time. Burgundy wines are similar to pinot noir, but only wines made from grapes grown in Burgundy can be titled as such. In the late 1980s, Drouhin purchased land in the Dundee Hills and established Domaine Drouhin Oregon, the first French-owned winery in the state. ${ }^{30}$

As Oregon wine began to receive intense national and international attention, winemakers found it necessary to teach each other, share their secrets, and admit their failings. Keep- ing with the regional industry's open and collaborative traditions, Stephen Cary and several others conceived of the Steamboat Conference in 1980. ${ }^{31}$ Fondly referred to as "Steamboat," documents regarding its founding describe the conference:

The first meeting drew 17 winemakers and friends of Pinot Noir. It lasted two days and two nights .... Initially finished wines, those already in bottle, were tasted and compared with other Pinots from around the globe, primarily Burgundy. As the event grew the format changed to include only wines produced by the attending wineries in the formal, blind tastings. ${ }^{32}$

The press was not invited. Attendees provided honest criticism during an open discussion of problem wines. The annual conference grew throughout the 1980 os and, although there is no official relationship, is now timed so that visitors attending the International Pinot Noir Celebration (IPNC) every year often attend Steamboat as well. The Oregon Pinot Camp (OPC), established in 2000, also grew from similar collaborative efforts. Filmed interviews and the booklets from every OPC conference record the itinerary and educational materials provided during the weeklong seminars. ${ }^{33}$

Despite international recognition and regional collaboration to improve products, Oregon wine was not selling well on local and national markets. The American market was not aware of much beyond a table wine and was not yet culturally conditioned to include wine as a regular part of the dining experience. As a result, during the early 1980 , indus- 
try members imposed an even higher tax on themselves to fund promotion and marketing and to raise their collective profile. The tax created what is now known as the Oregon Wine Board, whose records also are a part of OWHA. ${ }^{34}$ The collection includes shared advertising spreads, traveling tasting shows, marketing surveys, and television ads for "Drink Oregon!" Even after the intensive marketing effort, however, sales were still looking bleak in 1985. Members of the Oregon wine industry responded by hosting an event that has now passed into legend as the "Burgundy Challenge." Organized by Stephen Cary and held in New York's renowned International Wine Center, the Burgundy Challenge was a blind taste test to select the finest wines in the world. OWHA contains several articles documenting the stunning results: Tasters admitted that they could not distinguish which wines were from Burgundy and which were from Oregon. The top five wines were all Oregon vintages: Yamhill Valley Vineyards, Sokol Blosser Winery, Adelsheim Vineyard, The Eyrie Vineyards and Knudsen-Erath Winery. Oregon wine had become a phenomenon, and sales began to climb accordingly.

Industry leaders have worked to share their success with all who make it possible. Members more recently have worked to provide care for the predominantly Latino workers who substantially contribute to the industry every year. The Ponzi, WillaKenzie, and iSalud! collections of OWHA contain documentation of hours worked in the vineyard, daily assigned tasks, and compensation, showing that many Oregon vineyards and wineries have worked toward providing yearround employment and benefits to their workers in a bold departure from many other agricultural industries. The Oregon wine industry also created and supports ; Salud!, a free health-care program for vineyard workers and their families. As with many Oregon wine innovations, the idea to create and fund ;Salud! took a commitment from the majority of the industry in order to ensure the program's success. When asked if there was anything similar elsewhere in the wine industry, co-founder Nancy Ponzi says, "There is a really distinct thing here .... Almost every visitor here comments they can't believe that we really and truly work cooperatively on not only ;Salud!, but almost every other major [event]." ${ }^{35}$ Now in its twenty-second year, ;Salud! provides free access to health care, health education, and a mobile screening clinic. The program is largely funded through an annual wine auction and other events that now involve a majority of the Willamette Valley wine industry. OWHA is working with the Linfield Center for the Northwest during the summer of 2013 to document Latino involvement in the wine industry through historical documentation and oral histories, which include sub-themes of immigration, jSalud!, mentorship, and everyday life among vineyard workers.

The industry's cooperative and caring nature is made clear from many 


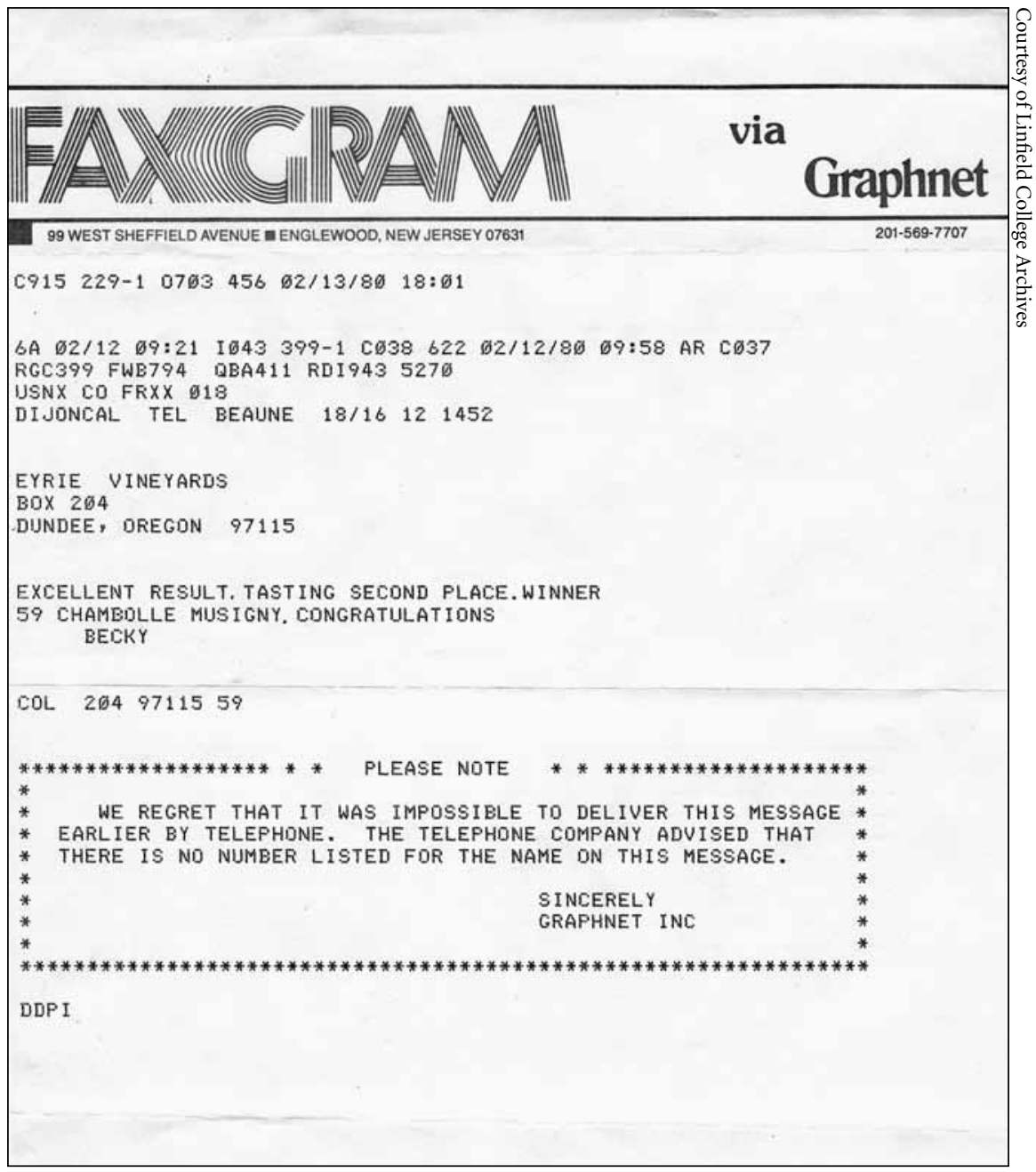

This fax relays the news of a second-place finish for The Eyrie Vineyards in a tasting organized by Robert Drouhin during February 1980. A 1959 Chambolle-Musigny took first place in the tasting.

of the early documents in several OWHA collections, including those regarding International Pinot Noir Celebration (IPNC) ${ }^{36}$ IPNC is now in its twenty-seventh year and is held annually on the last weekend of July on the Linfield College campus in
McMinnville. Originally, conference organizers intended to rotate among various wine-producing regions, but according to IPNC Director Amy Wesselman, the incredible amount of organization and communication required to annually put on a program 


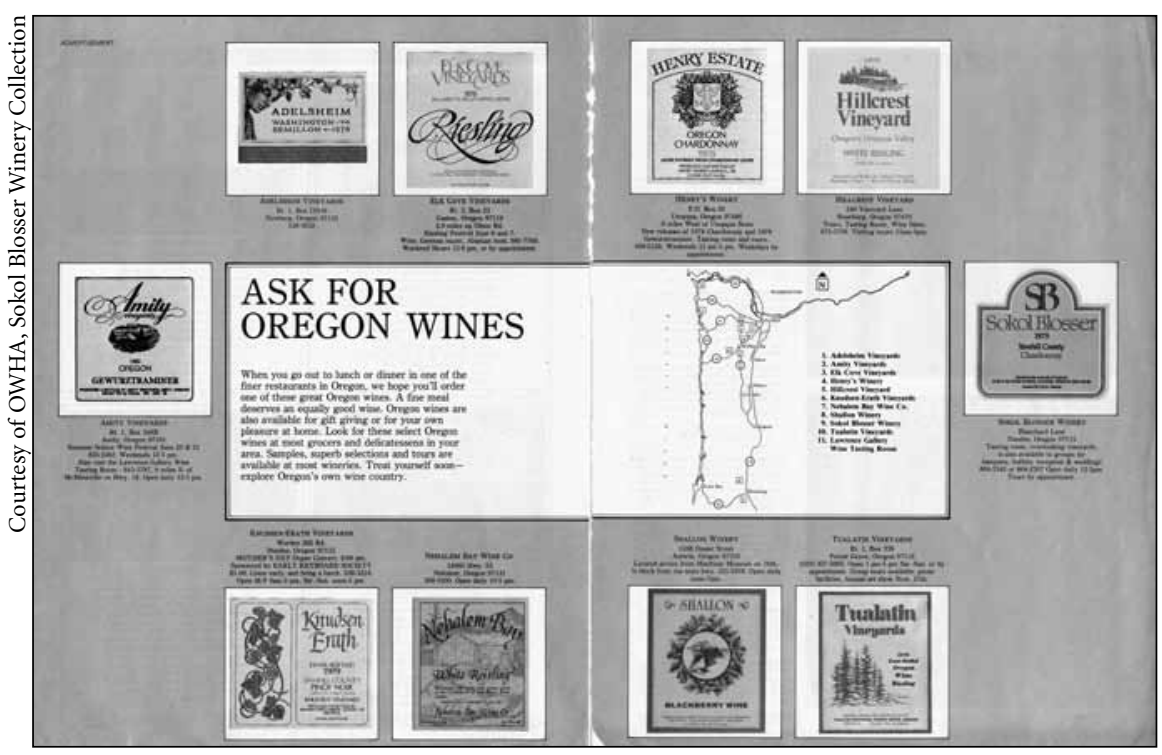

One of the early collaborative advertising efforts was this magazine spread from the late 1970s, encompassing wineries from across the state. The concept of "Oregon wine" as a brand was just starting to emerge.

for more than 800 attendees requires strong cooperation within the hosting wine community, and that simply does not exist outside of Oregon. ${ }^{37}$

Almost 165 years since the first pioneers planted vitis vinifera and 46 years since the first pinot noir was bottled, the story of Oregon wine continues to unfold with particular terroir elements intact: love for the land, continued partnership, exchange of knowledge, high quality of wine, and care for fellow industry members. When discussing passing the reins of his business to his daughter Luisa Ponzi, Dick Ponzi gives insight into how he sees the transition to the next generation of the Oregon wine industry:
Luisa's style and my style are pretty close. In fact, I have to say she's a little more sophisticated, a little more of a delicate touch. But the most rewarding thing for me was the times when we sat down together to taste the blends. At the beginning, I would formulate the batches. The next year I would be less influential. Over a four-year period I was out of the picture. It was, I've never told this to anybody, but it's like I didn't need to be there anymore. But I really enjoyed being a part of that transition. I've surrendered it to her completely..$^{38}$

There is a new generation of Oregon winemakers emerging, and it is for them to determine how Oregon wine will continue to evolve; whichever direction they choose, OWHA will continue to actively document Oregon wine's past, present, future, and terroir. 


\section{OREGON WINE HISTORY PROJECT AND COLLECTIONS}

During its first eighteen months of existence, OWHA materials have been used by Oregon Public Broadcasting in "Grapes of Place," an episode of Oregon Experience first broadcast in May 2012. Several authors writing about Oregon wine have also conducted research through the OWHA, and Linfield College students and faculty members have taken advantage of different aspects of the archives, studying marketing and business, exploring Latino history, producing documentary films, and conducting community engagement. The OWHA will continue to add newcollections while also fostering opportunities to grow existing collections. The OWHA has purposefully collected materials that document the many spheres that make up the wine industry; taken together, the collections will tell the unique story of Oregon wine.

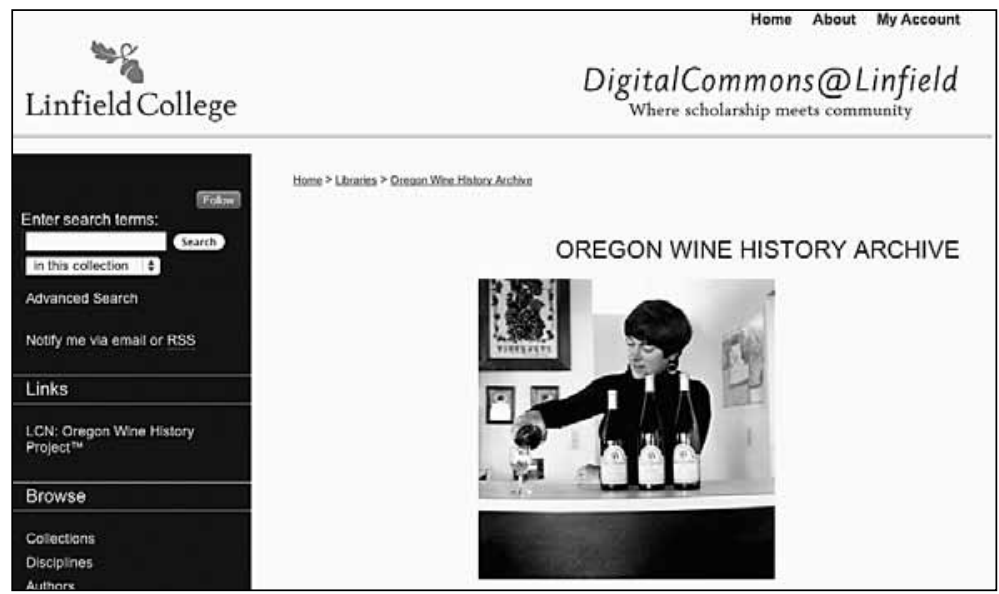

In keeping with Oregon wine's collaborative spirit, Oregon institutions with wine industry collections are working together to uncover, protect, and make available the historical records. In addition to the Oregon Wine History Archive at Linfield College, related historical materials can be found at the following institutions: the Douglas County Museum in Roseburg, the Oregon Historical Society in Portland, Oregon State University in Corvallis, the Southern Oregon Historical Society in Medford, Southern Oregon University in Ashland, and Southern Oregon Wine Institute in Roseburg. The OWHA is working to provide digital content of collections, exhibits, oral histories, and projects at DigitalCommons@Linfield: http://digitalcommons.linfield.edu/owha. Information and inventories for each processed collection can be found through a search of the Northwest Digital Archives, located on the Linfield College archives website: www.linfield.edu/archives.

With funding from the Oregon Cultural Trust, Linfield College has been able to process, digitize, and make these first collections available to the public. Recent funding from the Yamhill County Cultural Coalition, the Linfield Center for the Northwest, and the Oregon Wine Board will support summer 2013 projects to document, record, and exhibit the history of Latinos in the wine industry and the Southern Oregon wine producers. 
1. George Taber, In Search of Bacchus: Wanderings in the Wonderful World of Wine Tourism (New York: Scribner, 2009), 249; Patrick McGovern, Ancient Wine (Princeton: Princeton University Press, 2007), 58-60.

2. Scott Burns, "The Importance of Soil and Geology in Tasting Terroir with a Case History from the Willamette Valley, Oregon," in The Geography of Wine, ed. Percy H. Dougherty (New York: Springer, 2012), 95.

3. The Linfield Center for the Northwest is a Linfield College department with the objective of establishing long-term experiential learning practices with students that focus on local, regional, and global intersections with the Pacific Northwest. More on the IPNC's development, importance, and history will come later in this piece.

4.Paul Pintarich, The Boys Up North: Dick Erath and the Early Oregon Winemakers (Portland, Ore.: The Wyatt Group, 1997), 8.

5. Cole Danehower, Essential Wines and Wineries of the Pacific Northwest (Portland, Ore.: Timber Press, Inc., 2010), 32-33.

6. Also seen as Frank Reuter in some sources, however, Ernst Reuter is the more widely used name as seen in the Oregon Wine Press article covering the OPB documentary Oregon Experience: Grapes of Place, http://oregonwinepress.com/ article? articleTitle=fine-vine-viewing-1338403071--1236--wine_news (accessed April 4, 2013); Vitis vinifera is Latin for "common grape vine"; Judy Peterson-Nedry, Oregon Wine Country (Portland, Ore.: Graphic Arts Center Publishing Company, 1998), 25.

7. Danehower, Essential Wines and Wineries of the Pacific Northwest, 32-34. Primary materials can be found at Southern Oregon Historical Society, Roseburg, Oregon.

8. Pintarich, The Boys Up North: Dick Erath and the Early Oregon Winemakers, 2-3.
See also quoted news resources in Images of America: Rogue Valley Wine, 9-14.

9. Oregon Experience: Grapes of Place, DVD, produced by Nadine Jelsing, (Portland: Oregon Public Broadcasting, 2012).

10.Oregon's Prohibition officially went into effect Jan. 1, 1916, three years before the 18th amendment was passed to begin national Prohibition. "Prohibition in Oregon: the Vision and the Reality," Oregon State Archives, http://arcweb.sos.state.or.us/pages/ exhibits/5oth/prohibition1/prohibintro.html (accessed July 8, 2013).

11. "History of the OLCC," Oregon Liquor Control Commision, http://www.oregon. gov/olcc/docs/publications/about_us_ history.pdf (accessed July 8, 2013); "Oregon Liquor Control Commission: About," Oregon Liquor Control Commission, http:// www.oregon.gov/olcc/Pages/about_us.aspx (accessed March 15, 2013).

12. "Oregon Wine Board: History," Oregon Wine Board, http://oregonwine. org/wineries/history.aspx (accessed April 11, 2013).

13. "Viticulture and Enology: About Us," University of California Davis, http://wineserver.ucdavis.edu/content. php?category $=$ About $\% 20$ Us \&id $=144$ (accessed March 15, 2013).

14. Oregon Experience: Grapes of Place.

15. Interview from Janis Miglavs collection, Oregon Wine History Archive, Linfield College, McMinnville, box 1 of 1 (hereafter Oregon Wine History Archive).

16. Charles Coury, "Wine Grape Adaptation in the Napa Valley, California," (Ph.D. diss., University of California, 1952). Coury had a way with words, as shown in this quote from his thesis: "When a variety [of grape] gains such an ideal adaptation to its district, when it attains ecological harmony with its environment, when it produces consistently great wines, it is eulogised and the term 'noble variety' is bestowed." 
17. Oregon Experience: Grapes of Place. Let it be noted that another version of the story suggests that UC Davis professors cautioned cool-climate grapes could not be grown in a larger business capacity in Oregon, as opposed to suggesting it could not be done at all.

18. Susan Sokol Blosser, At Home in the Vineyard: Cultivating a Winery, an Industry, and a Life (Berkeley: University of California Press, 2006), 6; Pintarich, The Boys Up North: Dick Erath and the Early Oregon Winemakers, 8-22; J. Elizabeth Purser and Lawrence J. Allen, The Winemakers of the Pacific Northwest (Vashon Island, Wash.: Harbor House Publishing, Ltd., 1977), 157-63.

19. Oregon Experience: Grapes of Place.

20. Interview from Janis Miglavs collection, Oregon Wine History Archive box 1 of 1 .

21. Ibid.

22. David Adelsheim and David Lett, "Land Use Planning Maps, Oregon" (1973), Land Use Planning Maps: David Adelsheim Collection, http://digitalcommons.linfield. edu/land_use_maps (accessed March 15, 2013).

23. Amity Vineyards Collection, box 2, folder 2, Oregon Wine History Archive. This box and the Oregon Liquor Control Commission box within the Oregon Wine Board Collection (still being processed) have a great deal of information on those lobbying efforts.

24. Amity Vineyards Collection, box 2, folder 2, Oregon Wine History Archive.

25. "LEED," LEED, 2013, http://new. usgbc.org/leed (accessed March 15); "LIVE," LIVE Inc., http://liveinc.org (accessed March 15, 2013); "Salmon Safe," Salmon Safe, http:// www.salmonsafe.org (accessed March 15, 2013); Sokol Blosser Winery collection, Amity Vineyards collection, Oregon Wine History Archive.

26. Amity Vineyards Collection, box 2, folder 5. Additional related materials are in Erath Winery Collection, box 10, folder 1, and box 18, folder 7, Oregon Wine History Archive.

27. Letter from Winegrowers Council of Oregon, December, 1975, Gary Fuqua Papers, box 1, folder 17, Oregon Wine History Archive.

28. Letter dated December 26, 1978, from David Adelsheim entitled "The Clonal And New Varietal Testing Program," Amity Vineyards Collection, box 2, folder 5, Oregon Wine History Archive. The authority in France that gave this permission is now now known as ENTAV: Etablissement National Technique pour l'Amelioration de la Viticulture; see http://www.entav.com/.

29. "Excellent Result, 1980 Fax" (1980). Willamette Valley Archival Documents - Eyrie. Image. Submission 2. http://digitalcommons. linfield.edu/eyrie_docs/2.

30. Domaine Drouhin Oregon: http:// www.domainedrouhin.com/en/our-story. php (accessed April 11, 2013).

31. Stephen Cary papers, box 1, folder 1 , Oregon Wine History Archive.

32. Ibid.

33. Oregon Pinot Camp film collection and the Amity Vineyards collection, Oregon Wine History Archive.

34. Passing of the resolution is found in the executive board minutes of the Winegrowers Council of Oregon, July 6, 1977, Amity Vineyards Collection, box 2, folder 7, Oregon Wine History Archive.

35. Interview with Nancy Ponzi, May 23, 2013, and May 24, 2013; and interview with Ronni Lacroute, June 10, 2013, Oregon Wine History Archive. Interviews will eventually be part of Ponzi Vineyards Collection and WillaKenzie Estate Collection, respectively.

36. International Pinot Noir Celebration collection, Sokol Blosser Winery collection, Erath Winery collection, Oregon Wine History Archive.

37.Conversation with Amy Wesselman on February 13, 2012.

38. Interview from Janis Miglavs collection, Oregon Wine History Archive. 